YAK 347.77

\author{
Колос Сергій Степанович, \\ старший викладач кафедри права \\ Вінницького національного аграрного університету, \\ СУААЯ \\ Апеляційного суду Вінницької області у відставці
}

\title{
ЗАХИСТ ПРАВ ІНТЕЛЕКТУАЛЬНОÏ ВЛАСНОСТІ В КОНТЕКСТІ СУДОВОЇ РЕФОРМИ
}

Постановка проблеми. У сучасних умовах економічного розвитку України, розширення інтеграційних процесів стратегічного значення набуває питання ефективного захисту прав інтелектуальної власності.

УАосконалення захисту прав інтелектуальної власності в Україні $€$ одним із найважливіших питань реформування сфери інтелектуальної власності. Оскільки Україна взяла курс на євроінтеграцію й активно його реалізує після піАписання та ратифікації Угоди про асоціацію з Європейським Союзом, питання захисту прав інтелектуальної власності набувають Аодаткової ваги.

ПіАвищення рівня захисту прав інтелектуальної власності передбачає реалізацію багатьох завдань, пов'язаних як із удосконаленням законоАавства, правозастосовної практики, так і з активним залученням і постійною взаємодією органів державної влади, правоохоронних, фіскальних органів тощо. Істотна роль у цьому процесі віАвоАиться й судовій гілці влади, яка перебуває у сталії активного реформування, особливо враховуючи перспективу початку Аіяльності в Україні Вищого спеціалізованого суду з питань інтелектуальної власності.

Варто зазначити, що з прийняттям Цивільного кодексу України (Аалі - ЦК України) досліАження питань функцій, метоАів, принципів цивільного права набуло нового поштовху на рівні загальних засаА цивільно-правового регулювання.

ОАним із напрямів реформування судової системи України є поглиблення спеціалізації суААів, що стало насліАком формування окремого судового органу - Вищого спеціалізованого суду з питань інтелектуальної власності. Так, 2 червня 2016 р. Верховна Рада України прийняла зміни
Ао Конституції України [4] та Закону України «Про судоустрій і статус судАів" [3], якими ініційовано створення Вищого суду з питань інтелектуальної власності [8]. Зараз триває процес формування калрового скмаду новоствореного судового органу, визначення кола його повноважень і регламентація правових засад Аіяльності.

Стан АосліАження теми. Питання захисту прав інтелектуальної власності $€$ предметом АосліАжень таких сучасних учених: О.В. Гумеги, О.Ф. Аорошенка, І.Ф. Коваль, О.В. Кохановської, Н.С. Кузнєцової, А.Р. Майданик, Н.М. Мироненко, О.П. Орлюк, О.О. Підопригори, М.Ю. Потоцького, Р.О. Стефанчука, О.О. Харитонової, О.С. Харченко, Р.Б. Шишки, О.О. Штефан і низки інших. ОАнак на сучасному етапі реформування правового регу^ювання інтелектуальної власності, створення нового судового органу виникає необхідність більш Аетальних Аодаткових АосліАжень з даної тематики.

Мета стапті - розглянути основні проблеми захисту прав інтелектуальної власності в контексті судової реформи.

ВикиаА основного матеріалу АосліАЖення 3 повним обгрунтуванням отриманих наукових результатів. Право на судовий захист гарантується актами міжнародного права та нормами національного законодавства. Статтею $55 \mathrm{Koн}-$ ституції України закріплено, що права і свободи мюАини та громаАянина захищаються судом. Кожному гарантується право на оскарження в суді рішень, Аій чи безАіяльності органів державної влаАи, органів місцевого самоврядування, посадових і службових осіб. ВіАповіАно Ао змін, унесених до Конституції Законом України віА 02.06.2016 № 1401-VIII [4], кожному гарантується 


\section{4 回回回回回回回回回回回回回回回回回回回回回 Випуск 33}

право звернутися з конституційною скаргою Ао Конституційного Суду України з піАстав, установлених цією Конституцією, і в порядку, визначеному законом. Кожен має право після використання всіх національних засобів юридичного захисту звертатися за захистом своїх прав і свобод Ао віАповіАних міжнародних судових установ чи віАповіАних органів міжнародних організацій, членом або учасником яких є Україна. Кожен має право будь-якими не забороненими законом засобами захищати свої права і свободи від порушень і протиправних посягань. Зазначене право на захист утілено в кожній із галузей національного права.

Принципи судового захисту права та інтересу особи визначено в цивільному праві й цивільному законодавстві. Зокрема, наведений вище піАхіА щодо розуміння змісту захисту відображено в ст. 15 ЦК України, якою закріплено, що "кожна особа має право на захист свого права у разі його порушення, невизнання чи оспорювання, а також право на захист свого інтересу, який не суперечить загальним засадам цивільного законодавства" [9]. Це Аає підстави стверджувати, що захист визнається наслідком порушення, невизнання чи оспорювання права або охоронюваного законом інтересу, а тому захистом охоплюються лише передбачені законом засоби, що спрямовані на відновлення чи визнання прав і/або охоронюваних законом інтересів уповноважених суб'єктів. Його функціональним призначенням є відновити за Аопомогою правових засобів правове становище, що існувало Ао правопорушення, або компенсувати все, що було втрачене внаслідок його вчинення [10, с. 184-186].

Цивільно-правовий захист є принципом цивільного законодавства, інститутом цивільного права, інститутом цивільно-процесуального права. Право на захист $€$ конституційною гарантією та реалізацією суб'єктивного права особи вимагати віА уповноважених органів примусового застосування засобів реагування до порушників цивільних прав, склаАником певної системи організаційно-правових заходів, що вживаються в разі порушення цивільних прав та інтересів [2, с. 310].

За загальним піАходом, прийнятим у теорії права, захист прав, у тому числі прав інтелектуальної власності, може відбуватися шляхом застосування певних організаційних заходів (що можуть розгляАатися як внутрішньо погоджений комплекс), які прийнято називати формами захисту прав. При цьому основний поділ іде на юрисАикційну та неюрисдикційну форми захисту прав. ВіАповіАно, захист прав інтелектуальної влас- ності Аоцільно розгляАати як сукупність заходів, що їх застосовує правомочна особа самостійно чи шляхом звернення Ао компетентних органів, спрямованих на недопущення чи припинення порушення, оспорювання, невизнання або посягання на права інтелектуальної власності чи охоронювані законом інтереси в указаній сфері.

Саме такий висновок можна зробити з аналізу робіт вітчизняних авторів, які представляють різні галузі права, але об'єАнуються сферою інте^ектуальної власності, а також практиків. НаприклаА, на Аумку Н.М. Мироненко та М.В. Паладія, захист прав і законних інтересів суб'єкта права інтелектуальної власності реалізується через механізм захисту, що являє собою систему форм, способів і засобів Аіяльності відповіАних юрисАикційних органів і зацікавлених осіб. Елементами вказаного механізму захисту є норми права, суб'єкти захисту права інтелектуальної власності, юрисликційні органи Аержави [6, с. 48]. При цьому захисту підлягають особисті немайнові та майнові права інтелектуальної власності, що охороняються віАповіАно Ао закону (ст. ст. 423 й 424 ЦК України).

Порушення прав інтелектуальної власності може проявлятися, зокрема, у недодержанні сторонами піА час учинення правочину щодо об'єкта права інтелектуальної власності вимог закону (ст. 215, ч. 2 ст. 1107 ЦК України); порушенні права на визнання особи творцем об'єкта права інтелектуальної власності та права на використання ім'я (ст. 296, п. 1 ч. 1 ст. 423 ЦК України); неповазі до честі й репутації творця об'єкта права інтелектуальної власності (ст. 297, п. 2 ч. 1 ст. 423 ЦК України); порушенні права на використання об'єкта права інтелектуальної власності (ч. 1 ст. 424 ЦК України); неправомірному використанні об'єкта права інтелектуальної власності (ч. 2 ст. 424 ЦК України), зокрема неправомірному використанні твору без згоди автора (ст. 443 ЦК України), неправомірному використанні винаходу, корисної моделі, промислового зразка без згоди володільця віАповіАного патенту або іншого суб'єкта патентного права (ст. 464 ЦК України), неправомірному використанні торговельної марки без згоди володільця віАповіАного свідоцтва або іншого суб'єкта, визначеного законом чи Аоговором (ст. 495 ЦК України); невиконанні чи належному виконанні умов зобов'язання, предметом якого є права на об'єкт права інтелектуальної власності (ст. ст. 610, 1107, 1108, 1112, 1113 цК України) тощо. Спеціальне законодавство у сфері інтелектуальної власності дета- 
лізує виАи порушень щодо конкретних об'єктів права інтелектуальної власності. Невизнання особистого немайнового чи майнового права інтелектуальної власності полягає в запереченні наявності в особи суб'єктивного цивільного права на об'єкт права інтелектуальної власності (ст. ст. 422, 423, 424 ЦК України), на право користування (ст. 426 ЦК України) чи розпоряАження (ст. 427 ЦК України) таким об'єктом, на частку в об'єкті права інтелектуальної власності, що створений спільно кількома особами чи належить спільно кільком особам (ст. 428 ЦК України); на об'єкт права інтелектуальної власності, створений у зв'язку з виконанням трудового договору (ст. 429 ЦК України) тощо. Оспорювання особистого немайнового або майнового права інтелектуальної власності відбиває той стан правовіАношення, коли відповідне суб'єктивне цивільне право забезпечується в юрисаикційному органі. Якщо таким органом є суА, носій оспорюваного права може вимагати його визнання за Аопомогою звернення із зустрічним позовом.

Зокрема, Аля реалізації принципу судового захисту цивільного права й інтересу істотне значення має зміст ст. 16 ЦК України, якою закріплено загальні засади захисту цивільних прав та інтересів судом. Щодо безпосередньо сфери інтелектуальної власності цивільне законодавство деталізує особливості захисту права інтелектуальної власності судом у ст. 432 ЦК України. Застосований законодавцем підхіА до введення Аодаткових положень стосовно захисту прав інтелектуальної власності $є$ новелою Аля цивільного законодавства. Розробники ЦК України обумовили введення Аодаткових норм із деталізацією саме в частині судового захисту прав інтелектуальної власності.

Аля забезпечення захисту прав інтелектуальної власності суд може використовувати будь-які способи захисту, передбачені цивільним законоАавством, зокрема визнання права, визнання правочину неАійсним; припинення Аії, яка порушує право, віАновлення становища, яке існувало Ао порушення, примусове виконання обов'язку в натурі, зміна правовіАношення; припинення правовіАношення; відшкодування збитків та інші способи відшкодування майнової шкоди, віАшкодування моральної (немайнової) шкоди, визнання незаконними рішення, Аій чи бездіяльності органу державної влади.

Проте не всі способи мають однакове значення Аля захисту порушеного або оспорюваного права на результат інтелектуальної діяльності. Так, патентні права і права на засоби індивідуалізації засвідчуються фактом Аержавної реєстрації, тому поширеним способом їх оскарження буде вимога про визнання неАійсним виАаного охоронного Аокумента. 3 іншого боку, Аля захисту цієї групи прав не є характерним використання такого способу, як примусове виконання обов'язку в натурі, оскільки їх об'єктом є нематеріальні блага. Тому вибір способів судового захисту порушеного або оспорюваного права залежить віА характеру самого права, віА виду та характеру вчиненого правопорушення.

НаприклаА, особливим способом судового захисту, що застосовується в межах системи прав інтелектуальної власності, $€$ застосування разового грошового стягнення замість відшкодування збитків за неправомірне використання об'єкта права інтелектуальної власності. Варто наголосити, що у формулюванні відповідного положення ст. 432 ЦК України, яка встановлює цей спосіб захисту, зазначається, що "розмір стягнення визначається відповіАно до закону з урахуванням вини особи та інших обставин, що мають істотне значення". Тобто застосування разового грошового стягнення може мати місце лише в разі, якщо спеціальний закон про охорону певного об'єкта інтелектуальної власності Аопускає таку можливість. Як приклаА такої норми можна навести положення ст. 52 Закону України «Про авторське право і суміжні права" [7]. ОАнак Аля захисту інших об'єктів інтелектуальної власності цей спосіб захисту не може бути використаний через відсутність спеціальних законодавчих положень [5, с. 12].

ОчевиАно, що суАові спори щодо захисту прав інтелектуальної власності є оАними з найсклаАніших Аля розгляАу. Важливим напрямом реформування системи судового захисту прав інтелектуальної власності $€$ створення Вищого суду, що має на меті підвищення якості розгляду судових спорів у сфері інтелектуальної власності та скорочення термінів їх розгляду. Кількісний склаА Вищого суду з питань інтелектуальної власності передбачає 21 посаду судаів, які, крім проходження кваліфікаційного відбору, обов'язково повинні мати 5-річний стаж у галузі інтелектуального права. Структура суду включає апеляційну палату, яка буде переглядати рішення суду як апеляційна інстанція.

Підсудність Вищого суду з питань інтелектуальної власності включатиме такі види справ: у спорах щодо прав на об'єкти інтелектуальної власності (винахіА, корисну модель, торгівельну марку, промисловий зразок тощо), у спорах про облік 
і реєстрацію прав інтелектуальної власності, про визнання торгівельної марки відомою, у спорах щодо прав автора та суміжних прав, щодо уклаАання, зміни й інших Аій із майновими інтелектуальними правами, у спорах у сфері недобросовісної конкуренції [1].

Вищенаведений перелік не вичерпний. ОАнак, на Аумку фахівців, юрисАикція Вищого суду з питань інтелектуальної власності сформульована дуже розмито й у майбутньому Аля ефективної роботи вимагатиме уточнення та більш вузької спеціалізації.

Переваги створення Вищого суду з питань інтемектуальної власності, безумовно, великі, однак залишається відкритим питання початку роботи Суду та віАсутність чіткої юрисаикції й вузької спеціалізації. ОАнак, з огляду на надмірну завантаженість судів в Україні, виведення суперечок з інтелектуальної власності в окремий розгляА сьогодні $€$ дуже актуальним, тож $€$ сподівання що спеціалізований суА Аасть змогу піАвищити якість розгляАУ справ, напрацювати єАину судову практику без віАмінностей Аля цивільного й госпоАарського процесів, а також значно скоротити час розгляду справ.
Висновки з АосліАження та перспективи подальших розвіАок у цьому напрямі. Отже, незважаючи на Аостатньо реформовану законоАавчу базу, що забезпечує захист прав інтелектуальної власності, проблема ефективної реалізації судового захисту прав інтелектуальної власності в Україні залишається невирішеною, аАже склаАність судового розгляАу справ у сфері інтелектуальної власності, їх тривалість, віАсутність єАиних судових піАхоАів Ао вирішення цієї категорії спорів негативно впливають на рівень правової захищеності суб'єктів інтелектуальної власності. При цьому істотного значення набувають норми спеціального законодавства, в яких способи захисту прав на певні об'єкти права інтелектуальної власності Аеталізуються 3 урахуванням специфіки таких об'єктів. Створення Вищого спеціалізованого суду України з питань інтелектуальної власності передбачає можливість підвищення ефективності судового захисту прав інтелектуальної власності, а отже, Аасть змогу пришвиАшити розгляА справ, забезпечити якість їх розгляАу, напрацювавши єАину судову практику.

\section{NITEPATYPA:}

1. Господарський процесуальний кодекс України. Відомості Верховної Ради України (BВP). 1992. № 6. T. 56. URL: https://zakon.rada.gov.ua/laws/show/1798-12?find=1\&text=\%E2\%E8\%F9\%E8\%E9+\%F1\%F3\%E4+\%E7\#w11.

2. Гумега О. Реалізація принципів захисту прав інтелектуальної власності через призму людиноцентризму. Альманах права. Вип. 9. Київ: Ін-тут держави і права ім. В.М. Корецького НАН України, 2017. С. 307-312.

3. Про судоустрій і статус суддів: Закон України. Відомості Верховної Ради України (BВР). 2016. № 31. Cт. 545. URL: https://zakon.rada.gov.ua/laws/show/1402-19.

4. Конституція України. Відомості Верховної Ради України (ВВР). 1996. № 30. Ст. 141. URL: ttps://zakon.rada.gov.ua/laws/ show $/ 254 \% \mathrm{D} 0 \% \mathrm{BA} / 96-\% \mathrm{D} 0 \% \mathrm{~B} 2 \% \mathrm{D} 1 \% 80$.

5. Кординець А. Захист прав інтелектуальної власності в умовах впровадження судової реформи. Підприємництво, господарство і право. 2018. № 3. С. 8-13.

6. Право інтелектуальної власності: Науково-практичний коментар до книги четвертої Цивільного кодексу України / за заг. ред. М.В. Паладія, Н.М. Мироненко, В.О. Жарова. Київ: Парламентське вид-во, 2006. 432 с.

7. Про авторське право і суміжні права: Закон України від 23 грудня 1993 року. Відомості Верховної Ради Украӥни (ВВР). 1994. № 13. Ст. 64. URL: https://zakon.rada.gov.ua/laws/show/3792-12.

8. Про утворення Вищого суду з питань інтелектуальної власності: Указ Президента України від 29 вересня 2017 р. Офіційний вісник Украӥни. 2017. № 80. С. 11.

9. Ц Цивільний кодекс України. Відомості Верховної Ради України. 2003. № 40.

10. Цивільне право України: Загальна частина: у 2 т. / за ред. О.В. Дзери, Н.С. Кузнецової. 3-те вид., перероб. і доп. Київ: Юрінком Інтер, 2010. 976 с. 184-186.

\section{Колос Сергій Степанович}

\section{ЗАХИСТ ПРАВ ІНТЕАЕКТУАЛЬНОÏ ВААСНОСТІ В КОНТЕКСТІ СУАОВОЇ РЕФОРМИ}

У статті проаналізовано положення чинного законодавства України, що регулює захист прав інтелектуальної власності, АосліАжено особливості захисту прав інтелектуальної власності в контексті реформування судової системи. Розкрито положення теорії цивільного права щодо судового захисту прав інтелектуальної власності як одного факторів, що визначають особливості реалізації принципу захисту цивільних прав та охоронюваних інтересів у сфері інтелектуальної власності, окреслено перспективи роботи Вищого суду з питань інтелектуальної власності.

Киючові слова: інтелектуальна власність, захист прав інтелектуальної власності, судовий захист, Вищий суА з питань інтелектуальної власності. 


\section{Колос Сергей Степанович}

\section{ЗАЩИТА ПРАВ ИНТЕМЕКТУАЛЬНОЙ СОБСТВЕННОСТИ В КОНТЕКСТЕ СУАЕБНОЙ РЕФОРМЫ}

В статье проанализировано действующее законодательство Украины, регулирующее защиту прав интемлектуальной собственности, исследованы особенности защиты прав интемлектуальной собственности в контексте реформирования и создания Высшего суда по вопросам интемлектуальной собственности. Проанализированы положения теории гражАанского права по судебной защите прав интеммектуальной собственности как один из факторов, определяющих особенности реализации принципа защиты гражданских прав и охраняемых интересов в сфере интемлектуальной собственности, сформулированы выводы по совершенствованию национальной системы правовой охраны интемлектуальной собственности.

Киючевые слова: интемлектуальная собственность, защита прав интемлектуальной собственности, судебная защита, Высший суА по вопросам интемлектуальной собственности.

\section{Kolos Serhii}

\section{PROTECTION OF INTELLECTUAL PROPERTY RIGHTS IN THE CONTEXT OF JUDICIARY REFORM}

As Ukraine has taken the course on European integration and is actively implementing it after the signing and ratification of the Association Agreement with the European Union in 2014 and its entry into force on September 1 , 2017 , the issue of protection of intellectual property rights is gaining great importance.

Improving the protection of intellectual property rights involves implementation of many tasks related to both the improvement of legislation, law enforcement practice and active involvement and constant interaction of state authorities, law enforcement, fiscal authorities, etc., as well as development of appropriate legal mechanisms. The judicial branch of power, which is in the stage of active reformation, plays a significant role in this process.

Reforming of Ukrainian judicial system involves deepening of the specialization of judges, which is a result of the formation of a separate judicial body - the High Specialized Court on Intellectual Property.

The right to judicial protection is guaranteed by acts of international law and the norms of national legislation. Article 55 of the Constitution of Ukraine stipulates that human and citizen rights and freedoms are protected by court. Everyone is guaranteed the right for judicial appeal against decisions, actions or inactivity of state authorities, local governments, acting officials and civil servants.

For the implementation of the principle of judicial protection of civil law and interests, the content of Article 16 of the Civil Code of Ukraine, which establishes the general principles for the protection of civil rights and interests by a court, is of fundamental importance. In order to ensure the protection of intellectual property rights, the court may use any means of protection provided for by civil law.

Intellectual property disputes are among the most difficult to deal with. Taking into account the overload of courts in Ukraine, the resolution of intellectual property disputes in a separate consideration today is of great current interest, so there are expectations that the High Specialized Intellectual Property Court will improve the quality of case handling, develop a unified judicial practice without distinction for civil and economic processes, as well as significantly reduce the time for dealing with cases.

Key words: intellectual property, protection of intellectual property rights, judicial protection, the High Specialized Intellectual Property Court. 